J. Perinat. Med.

6 (1978) 80

\section{Fetal heart rate patterns during forceps operation}

\author{
Mario Zilianti, Freddy Cabello, Miguel Angel Estrada
}

Research Department and Department of Pediatrics at Maternidad Concepcion Palacios, Caracas, Venezuela

\section{Introduction}

Despite an enormous amount of work on changes in fetal heart rate evoked by uterine contractions during labor, many unanswered questions as to the pathophysiology and prognostic significance of the heart rate patterns ramain open to debate.

It is currently taught that early decelerations, or type $1 \mathrm{Dip}$, are related to the compression of the fetal head in the birth canal, late decelerations, or type $2 \mathrm{Dip}$, to placental insufficiency and variable decelerations to cord compression. All these patterns are elicited by, and by definition related to, the uterine contractions.

With the increasing use of electronic fetal heart rate monitoring these standard interpretations are currently being challenged, especially by people engaged both in clinical research and active obstetric practice $[2,4,17,18,19,21]$.

As far as early deceleration or type 1 Dip is concerned, its frequency $[2,3]$ is surprisingly low in relation to the constant phenomenon, that supposedly causes it: namely, compression of the fetal head in the birth canal during the uterine contractions. Nor is it more frequent when both uterine activity and the obstacle to the passage of the head are greater, as in cephalo pelvic disproportion. On the other hand, early deceleration can be seen in cases of floating head and intact membranes and also in breech presentation. Finally, the claim that the early deceleration is innocuous needs a thorough revision $[2,12 \mathrm{a}, 23]$.

\section{Curriculum vitae}

Italian born, living in Venezuela since 1951, Doctor MARIO ZILIANTI received his medical degree in Firenze in 1950. From 1951 until 1958 he worked in chest hospitals and received a full training in cardiorespiratory pathophysiology. He made his postgraduate course in Obstetrics and Gynecology at Maternidad Concepcion Palacios (Caracas) and was a research fellow at Columbia Presbyterian Medical Center, New York from 1963 to 1964.

Since then he has been working in the Research Department of Maternidad Concepcion Palacios, which is directed by Professor Oscar Agüero. He runs a busy obstetrical practice and since 1966 he has also headed the Ultrasound Department of the hospital.

In an attempt to establish the relation between fetal head compression and type 1 Dip, we studied heart rate evolution during forceps operation. Factors related to placental insufficiency or cord problems were largely eliminated by performing the operative manoeuvres during the intervals between uterine contractions and excluding the cases with overt cord complications at birth.

\section{Patients and methods}

Thirty-one patients at term constituted this study group. In 28 instances, decision to deliver by for- 
ceps was made because of poor expulsive efforts related to the epidural analgesia. In one case, the operation was performed because of transverse arrest and in two because of persistent posterior position. All were low or midlow forcepsoperations.

All forceps operations were performed by one of the author's using the LUNIKART's instrument.

The composition of the study group in relation to several variables is shown in Tab. $I$.

Uninterrupted recordings of fetal heart rate and intraamniotic pressure began once the patients had reached 4-6 cm. dilation and were continued up to the immediate neonatal period, according to techniques previously described [22]. Intraamniotic pressure and the fetal EKG were obtained by means of a transabdominal or transcervical intraamniotic catheter and a scalp electrode, respectively, and were recorded through a 4 channel recording unit*. Chart speed was maintained at $0.25 \mathrm{~mm} / \mathrm{sec}$. during labor. Higher speeds were used during forceps operation.

Fetal heart rate evolution was studied during several phases of the procedure: forceps application, locking of the blades, first traction and crowning of the fetal head and finally forceps withdrawal. Whenever heart rate changes were observed, the manoeuvre was interrupted, e.g. the blades were unlocked or traction released. In this way, a double cause-effect relationship could be established.

Orciprenaline was used at the beginning of the study to stop uterine activity and thus prevent

Tab. I. Composition of the population of 31 patients.

\begin{tabular}{lrr}
\hline $\begin{array}{l}\text { Primigravida } \\
\text { Multiparous }\end{array}$ & 5 \\
Labor (hours) & 26 & \\
2nd Stage (hours) & & $8.20 \pm 3.10$ \\
Orciprenaline & 6 & $0.57 \pm 0.30$ \\
Oxytocin & 18 & \\
Epidural & 29 & \\
Thiopentone & 1 & \\
Pudendal Block & 1 & \\
APGAR score 1 minute & $\geqslant 7: 22$ & \\
& $\leqslant 6: 9$ & \\
APGAR score 5 minutes & $>7: 30$ \\
& $<6: 1$ \\
\hline
\end{tabular}

\footnotetext{
* Hewlett Packard 7784 A
}

interferences with fetal heart rate evolution. We desisted after a few cases, because of severe postpartum hemorrhage and decided to follow the alternate scheme of carryingout forceps manoeuvres only during the intervals between uterine contractions. Furthermore in an attempt to avoid heart rate changes related to umbilical cord compression, cases with overt cord complications at birth were excluded from this study.

Since forceps manoeuvres were carried out between uterine contractions we could not use the current classification based on the relation of F.H.R. and uterine activity. Instead, we classified the decelerations according to their shape and the time necessary to complete the evolution from normal baseline to descent and back to normal rate again. Under these criteria, decelerations could be grouped in three fundamental patterns: 1) V shaped evolution which is completed in 20 seconds or less 2) $U$ shaped deceleration, completed in more than 20 seconds and 3) $\mathrm{W}$ deceleration which is variable in shape and generally completed in more than 20 seconds. Other nomenclature and baseline patterns follow the classification currently used in American Literature.

It may be mentioned here that a classification based on the shape of fetal heart rate evolution was used by HoN in 1960 [6]. Since then HoN himself and other authors have proposed many and more elaborate classifications but no one has proved that they have a superior prognostic capability in comparison to the simpler ones.

\section{Results}

Heart rate patterns were initially classified into 16 types, but were reduced to 7 by combining those patterns which were fundamentally similar (See legend Tab. II).

Changes in baseline and patterns of transient decelerations observed during forceps operation are presented in Tab. II, while baseline values and the amplitude of decelerations are presented in Tab. III.

Forceps application: Steady normal baseline with slight oscillations are predominant during forceps application. Mild V shaped decelerations are 
Tab. II. Fetal heart rate evolution during labor and successive phases of forceps operation.*

\begin{tabular}{lrrrrrr} 
& 15 & 4 & 6 & 6 & - \\
\hline Predominant pattern during labor & 17 & 12 & 1 & 1 & - & - \\
Forceps application & 17 & 6 & 4 & 6 & 2 & 2 \\
Locking of the blades & 3 & 12 & 8 & 10 & 2 & 2 \\
First tractions & - & 1 & 2 & 3 & 25 & - \\
Final traction and crowning of the fetal head & 4 & - & - & - & - & 1 \\
Forceps withdrawal & & & & &
\end{tabular}

* In a few occasions locking of the blades and tractions were repeated several times.

Explanation for symbols:

$\longrightarrow$ : Steady normal baseline, slight oscillations or accelerations.

V : V shaped deceleration

$W$ : W shaped deceleration

U : U shaped deceleration

Transient decelerations were occasionally anticipated and/or followed by slight accelerations.

$\longrightarrow$ : After the initial deceleration there is no heart rate recovery and bradycardia persist after the manoeuvre is interrupted.

$\uparrow$ : Rebound tachycardia (from bradycardia).

$\rightarrow \quad$ : Persistent bradycardia.

Tab. III. Average fetal heart rate before and during several phases of forceps operation. The average amplitude of decelerations is also shown. Ranges are given in parenthesis.

Previous baseline

$$
146 \pm 26.14
$$

Forceps application Average heart rate $\quad 136.53 \pm 25.35$

Amplitude of decelerations $43.33 \pm 12(20-75)$

Locking of the blades Average heart rate

$126.39 \pm 32.53$

Amplitude of decelerations $52.29 \pm 20.38$ (25-90)

First tractions Average heart rate $95 \pm 27.50^{2}$

Amplitude of decelerations 60

$\pm 24.70(15-100)$

Final traction and crowning

of the fetal head

Average heart rate

$82.21 \pm 35.57$

Amplitude of decelerations

$76.31 \pm 18.21(35-105)$

Forceps withdrawal and

delivery of the head

Average heart rate

$83.04 \pm 37.42$

Amplitude of decelerations $78.29 \pm 17.91$ (50-105) numerous; frequently heart rate normalizes while performing the manoeuvre.

Locking of the blades: Steady normal baseline still predominates in this stage. Decelerations are numerous and are distributed almost equally between $\mathrm{V}, \mathrm{W}$ and $\mathrm{U}$ shaped evolution. Their amplitude is greater than in the previous phase. Heart rate normalization generally occurs when the forceps is properly adjusted to the smaller diameter of the fetal head. Persistent bradycardia and rebound tachycardia are occasionally seen.

First tractions: This manoeuvre is characterized by a sharp decrease in the number of cases maintaining a normal baseline and an increase of the incidence and amplitude of the decelerations. $V$ shaped decelerations are numerous, but $\mathrm{W}$ and $\mathrm{U}$ decelerations are predominant. They typically normalize upon the releasing of traction. Persistent bradycardia or rebound tachycardia are occasionally seen. 

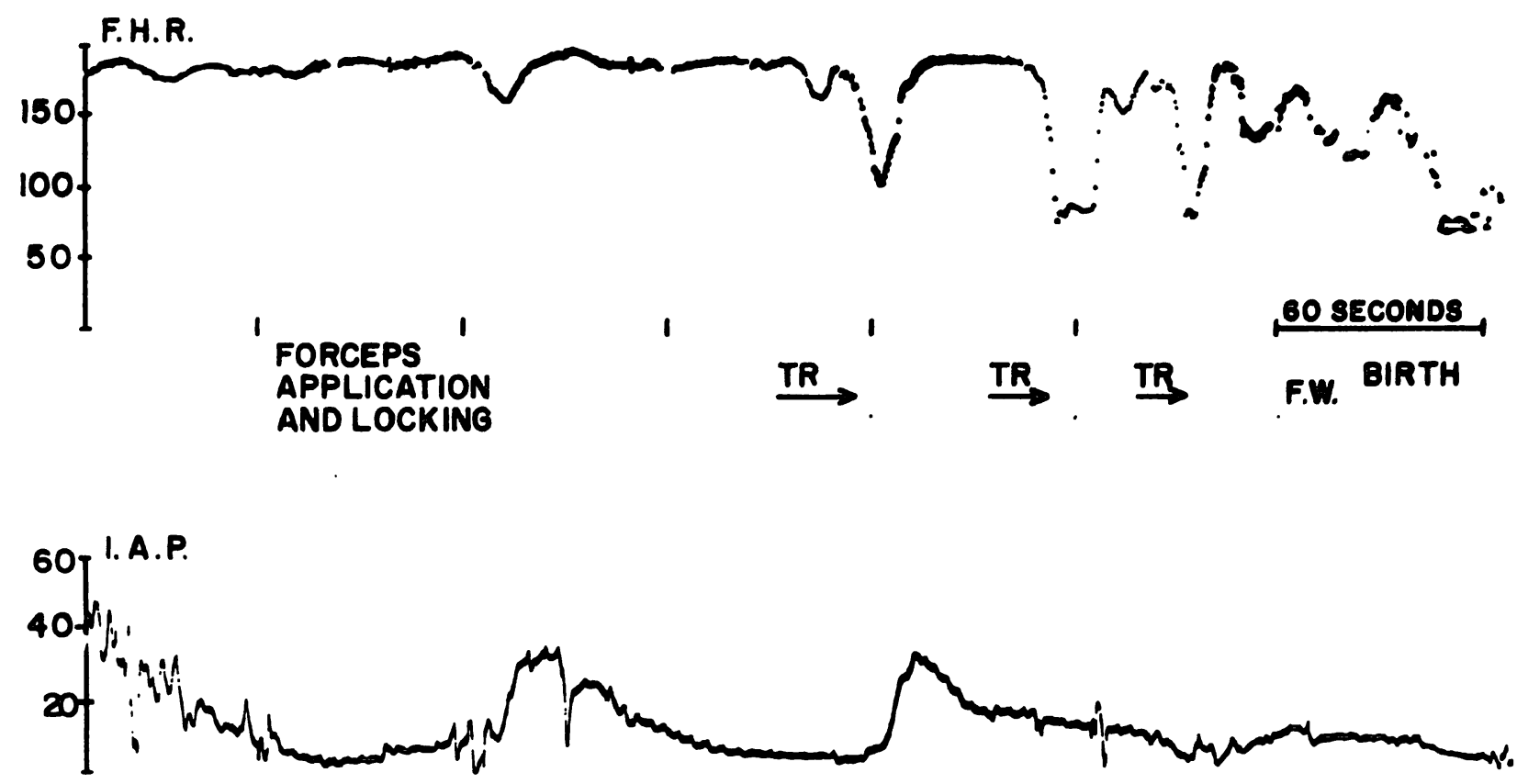

Fig. 1. Chart speed $0.5 \mathrm{~mm}$ per second. R.O.A., station + 3. First tractions: no rotation is attempted and there is no descent of the fetal head. $V$ shaped evolution of fetal heart rate closely follows traction (TR) and release. Second traction and rotation to 0 degree and third traction are followed by rapid heart rate drop and recovery once the pull is released. Birth bradycardia appears after forceps withdrawal (FW) and delivery of the head. Fetus APGAR 8-10.
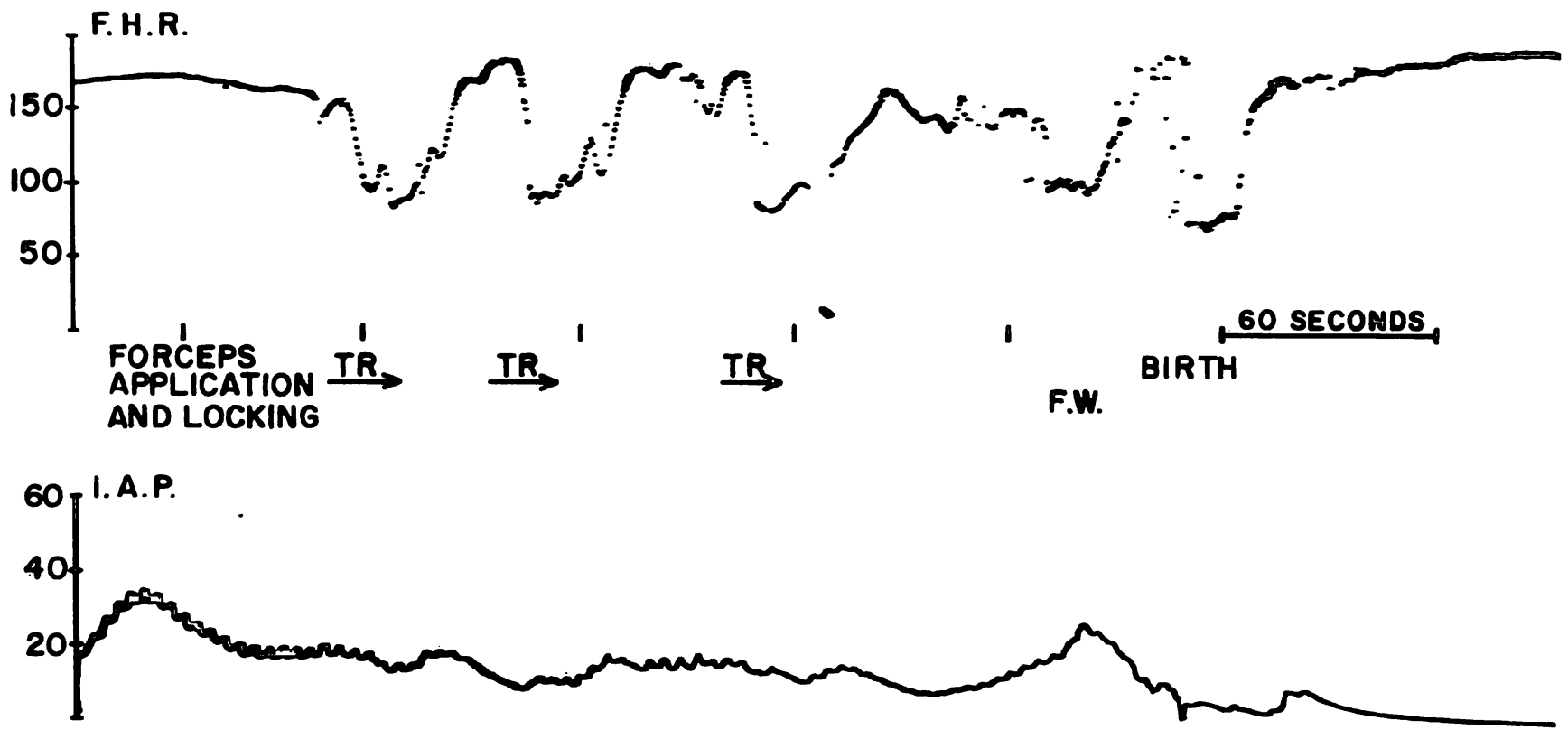

Fig. 2. Chart speed $0.5 \mathrm{~mm}$ per second. R.O.A., station + 4. No fetal heart rate changes are observed after forceps application and locking of the blades. After each traction (TR), heart rate drops rapidly to $75-80$ beats per minute and normalizes after traction is released. Heart rate recovery is irregular and is progressively slower (W evolution). Birth bradycardia appears after forceps withdrawal (FW) and delivery of the head. Fetus APGAR 7-9. 


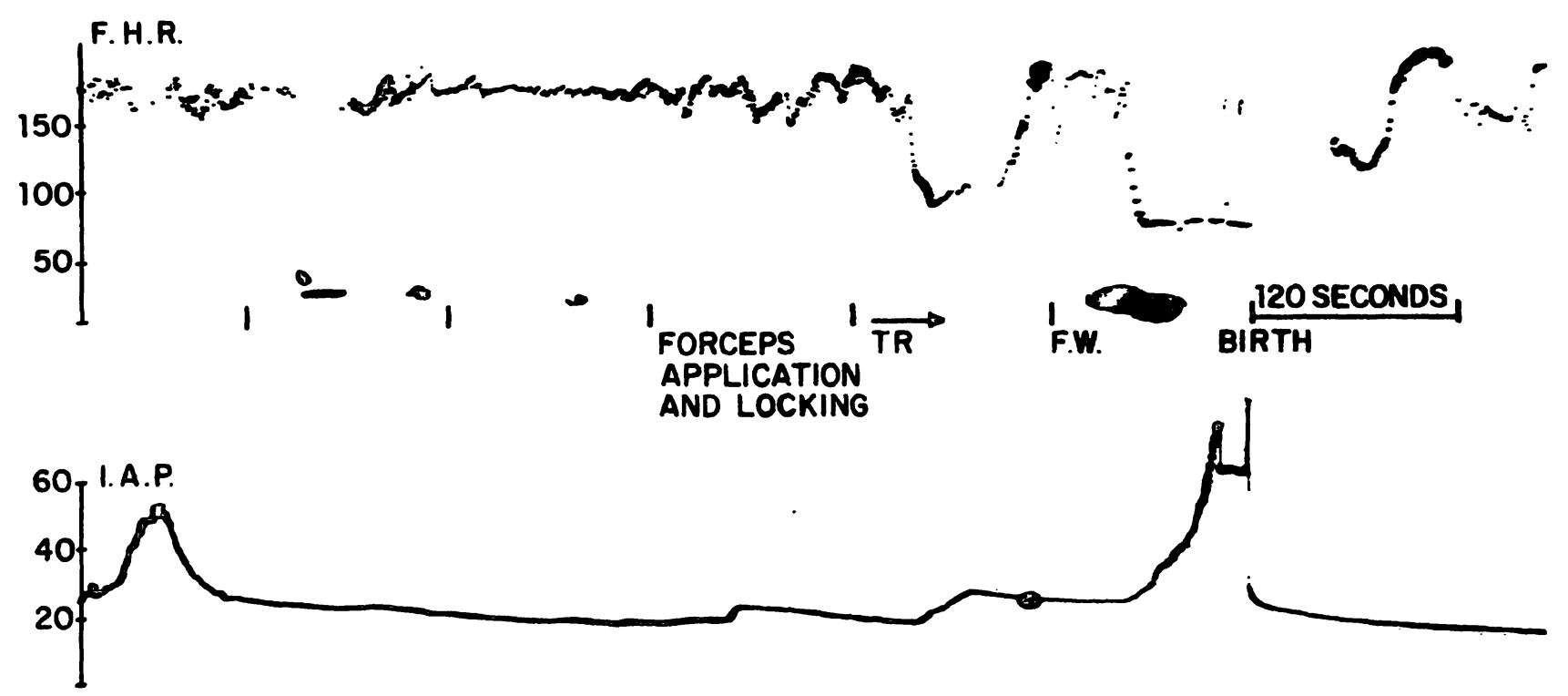

Fig. 3. Chart speed $0.25 \mathrm{~mm}$ per second. Slight oscillations are observed during forceps application and locking of the blades. The first prolonged traction induces bradycardia that slowly subsides after the pull is halted. (U evolution). Birth bradycardia appears at the crowning of the fetal head and persist after forceps withdrawal (FW). Fetus APGAR 7-8.

Final traction and crowning of the fetal head: A fall to persistent, deep bradycardia predominates during this phase. Heart rate recovery upon releasing of traction is rare.

Forceps withdrawal: At this time, when the fetal head is still crowning, few cases normalize their frequency and generally bradycardia persists.

We failed to establish a relationship between the heart rate patterns recorded during forcepsoperation and those observed during labor (Tab. II).

In this series there were 9 fetuses with a low 1 minute APGAR score and only one depressed baby at 5 minutes of life. Bradycardia which persisted after the manoeuvre was interrupted and rebound tachycardia were observed 8 times at the moment of locking of the blades and of the first traction. In seven instances this corresponded to mildly depressed fetuses.

\section{Comments}

The literature on the cardiovascular responses to fetal head compression by natural forces or obstetrical instruments is copious and starts with the obligatory historical reference of KERGARADEC $[10]$ as the first man who heard or at least wrote on fetal heart rate transient deceleration during uterine contractions. Several years later attention was focused on the amount of pressure necessary to evoke heart rate changes and on the mechanisms involved in their production. Ingenious electronic devices were also applied to the obstetrical forceps to quantitate the amount of pressure applied to the fetal head and to establish the security limits of such pressure $[9,16]$. This group of studies made clear that a threshold value of $40 \mathrm{~mm} \mathrm{Hg}$ of intraamniotic pressure or a forceps pull of 10 pounds intensity had to be reached to eventually evoke heart rate deceleration [8].

Natural forces during labor also lead to increased intracranial pressure. In semi experimental conditions [14] it was shown that the increase of intraamniotic pressure is paralleled by the intracranial pressure and that heart rate decelerations occur once the threshold value is reached. Heart rate fall was also evoked by solely increasing intracranial pressure.

Several authors have studied the mechanisms that lead to heart rate deceleration. The phenomenon is reflex in nature and mediated by the vagus since in some circumstances it is blocked by atropine [12]. The stimulus could be initiated by increased pressure on the vagus center or by a baroceptor response via vagus nerve to the systemic hyper- 
tension also evoked by high intracranial pressure [7].

Neural mechanisms are probably the first to cause the bradycardia, but there is experimental evidence of a biochemical change relating to the lowering of brain oxygenation including the vagal nuclei which prolongs the neural component $[11,13,15]$. It therefore is reasonable to expect a variety of shapes of cardiac decelerations depending on the variations in the stimuli. A standard response would be more difficult to explain. This especially applies to head compression by uterine contractions during labor and its supposed association with type 1 Dip.

Arellano and Caldeyro [1] and Chung and HoN [5] tried to give experimental support to this hypothesis. In the Montevideo study, the pressure on the fetal head was applied trans-abdominally and over a very small area. It is probable that only a moderate increase of the intracranial pressure was obtained. Furthermore, the stimulus was applied during uterine contractions and cases with cord complications were included in the study. The Montevideo groupalso demonstrated in another study, that cases with cord entanglement had a higher percentage of type 1 Dips [3]. CHUNG and HoN applied the pressure to the fetal head directly over a symmetrically wide area and during the intervals between uterine contractions but no reference is made to indicate if cases with cord problems were taken into account. The same authors in numerous successive publications repeated the concept that "cephalic compression is assumed to be the main cause of type 1 Dip" and that "V shaped bradycardia is thought to be due to increased intracranial pressure". The belief that this type of deceleration is physiological and of no pathological consequence is based on those statements $[3,6]$.

The results of our study agree only in part with this concept. $V$ shaped bradycardia certainly occurs during head compression but it is not the unique pattern. It prevails at the moment of forceps application but its frequency decreases when the pressure applied by the instrument is higher. In fact, during the locking of the blades and the first tractions, $U$ and $W$ shaped decelerations prevail.

In other words, there is no specific and single pattern of heart rate deceleration in response to head compression. The shape of the decelerations bears a relationship to the amount and duration of such compression.

If the effects of head compression caused by forceps or by uterine contractions are similar, the results of this study could lead to the conclusion that $U$ or W shaped decelerations recorded during labor are not necessarily related to utero placental insufficiency or cord problems but can also be the results of a strong head compression in the birth canal.

Tab. II shows that there is no relation between heart rate deceleration during labor and those observed during forceps delivery. On the contrary we confirm the observation of KELLY and CHUNG and HoN of more severe patterns in cases of fetal asphyxia $[5,8]$. Bradycardia which persists after the manoeuvre is interrupted and rebound tachycardia were observed in 8 cases. Seven of these cases correspond to mildly depressed fetuses.

The scheme of pull-deceleration and releaserecovery does not apply to the traction that brings about the crowning of the fetal head. In this phase, bradycardia persists after traction is halted and forceps withdrawn.

This phenomenon is also observed during spontaneous deliveries and therefore is not related to the instrument. We have already proposed a marked decrease of the umbilical placental circulation and its hemodynamics and biochemical implications as the cause of this birth-bradycardia [22].

\section{Summary}

Despite and enormous amount of work on changes in fetal heart rate during labor, many unanswered questions remain and agreement as to the mechanisms of production and prognostic significance is still open to debate.

Several recent studies show that the "ominous" heart rate patterns have a very low predictive value. On the

contrary, serious fetal problems including intrapartum death have been observed in the presence of "physiological" cardiac decelerations.

To examine this topic we decided to study the effects of head compression on fetal heart rate, during forceps operation. 


\section{Patients and methods}

Thirty-one patients at term constitute this study group. All infants were delivered by low or mid low forceps operations. Uninterrupted recording of fetal heart rate and intraamniotic pressure began once the patient had reached $4-6 \mathrm{~cm}$ and was continued up to the immediate neonatal period. Fetal heart rate evolution was studied during several phases of the operation: forceps application, locking of the blades, first traction, final traction and crowning of the fetal head and finally forceps withdrawal.

In an attempt to eliminate heart rate variations related to uterine activity and cord problems, the manoeuvres were performed during the intervals between uterine contractions and cases with cord entanglement were excluded from this study.

Heart decelerations were classified according to their shape.

Results. Fig. 1-3. Tab. II-III.

Forceps application: Steady normal baseline with slight oscillations are predominant. Mild V shaped decelerations are numerous; frequently heart rate normalizes while performing the manoeuvre.

Locking of the blades: Steady normal baseline still predominates. Decelerations are numerous and distributed almost equally between $\mathrm{V}-\mathrm{W}$ and $\mathrm{U}$ shaped evolution. Their amplitude is greater than in the previous phase. Persistent bradycardia and rebound tachycardia are occasionally seen.
First tractions: Very few cases maintain normal baseline. There is a sharp increase in the number and amplitude of decelerations. V shaped decelerations are numerous but $\mathrm{W}$ or $\mathrm{U}$ decelerations are predóminant. Persistent bradycardia and rebound tachycardia are occasionally seen. Heart rate typically normalizes once the manoeuvre is interrupted.

Final traction and crowning of the fetal head: $A$ fall to persistent bradycardia which persists upon releasing of traction clearly predominates in this phase.

Forceps withdrawal: Bradycardia persists.

\section{Comments}

V shaped bradycardia certainly occurs during head compression but it is not the unique pattern. It prevails during forceps application and its frequency decreases when the pressure applied by the instrument is higher when $U$ and $W$ shaped decelerations prevail. If the effects of head compression produced by forceps or uterine contractions are similar, $\mathrm{U}$ or $\mathrm{W}$ shaped decelerations recorded during labor could also be the results of a strong head compression in the birth canal and not necessarily be due to placental insufficiency or cord problems.

We found no association between heart rate patterns recorded during labor and the deceleration observed at the time of forceps manoeuvres. Furthermore, more severe heart rate patterns occurred in cases of depressed fetuses.

Final bradycardia is not related to the forceps and also occurs during spontaneous deliveries.

Key words: Fetal head compression, forceps, heart rate, V, W, U shaped decelerations.

\section{Zusammenfassung}

Fetale Herzfrequenzmuster während der Zangengeburt Trotz einer enormen Anzahl von Untersuchungen der fetalen Herzfrequenz während der Wehen bleiben viele Fragen unbeantwortet, und gerade im Hinblick auf den kausalen Mechanismus sowie die prognostische Bedeutung stehen übereinstimmende Ergebnisse noch aus. Mehrere Untersuchungen aus neuerer Zeit zeigen, daß ,unheilverkündende" Herzfrequenzmuster einen sehr niedrigen prognostischen Aussagewert haben. Im Gegensatz dazu steht, daß schwerwiegende fetale Komplikationen einschließlich des Todes intrapartum in Anwesenheit von "physiologischen" Herzdezelerationen beobachtet worden sind. Um diesen Punkt zu überprüfen, untersuchten wir den Effekt von Kopfkompressionen auf die fetale Herzfrequenz während der Zangenoperation.

\section{Material und Methoden}

Das Untersuchungskollektiv bestand aus 31 Patientinnen am Termin. Alle Kinder wurden unter leichter bis mittelstarker Zangenanwendung geboren. Die kontinuierliche Aufzeichnung der fetalen Herzfrequenz sowie des intraamniotischen Druckes wurde begonnen, wenn der Muttermund 4-6 cm eröffnet war, und bis zum Eintritt in die neonatale Phase durchgeführt. Der Verlauf der fetalen Herzfrequenz wurde während der verschiedenen Phasen der Operation untersucht: Applikationder Zange,Schließen der Zangenblätter, 1. Traktion, Freilegung des fetalen Kopfes und Entfernung der Zange. Um Herzfrequenzänderungen, die auf uterine Aktivitäten und Nabelschnurkomplikationen zurückzuführen sind, auszuschließen wurden die Vorgänge während der Intervalle zwischen den Uteruskontraktionen ausgeführt, und Fälle mit Nabelschnurumschlingung schieden aus dieser Untersuchung aus. Herzdezelerationen wurden nach ihrem Profil klassifiziert. Ergebnisse: Fig. 1-3; Tab. II-III.

Zangenapplikation: Eine stetige normale Basislinie mit leichten Oszillationen ist vorherrschend. Dezelerationen mit einem leicht V-förmigen Profil finden sich häufig; die Herzfrequenz normalisiert sich im Fortlauf dieses Anwendungsschrittes.

Schließen der Zangenblätter: noch immer dominiert die normale Basislinie. Dezelerationen sind zahlreich und verteilen sich fast gleichmäßig auf Profile mit V-, W- und U-förmigem Verlauf. Ihre Amplitưde ișt größer als in der vorhergehenden Phase. Persistierende Bradykardie und eine nachfolgende plötzliche Tachykardie werden gelegentlich beobachtet.

Erste Traktion: Nur in wenigen Fällen bleibt die normale Basislinie erhalten. Es ist ein deutlicher Anstieg hinsicht- 
lich der Zahl sowie Amplitudenhöhe der Dezelerationen zu beobachten. V-förmige Dezelerationen sind vorhanden, aber W- oder U-formige Dezelerationen herrschen vor. Persistierende Bradycardie und anschließende Tachykardie wurde gelegentlich beobachtet. Die Herzfrequenz normalisicrte sich, wenn die Traktion unterbrochen wurde.

Letzte Traktion und Freilegen des fetalen Kopfes: Es dominiert in dieser Phase ganz deutlich eine persistierende Bradykardie, die auch nach der Beendigung der Traktionen fortdauert.

Entfernen der Zange: die Bradycardie dauert an.

\section{Diskussion}

V-förmige Bradycardien ereignen sich bei Kopfkompressionen, aber sie stellen nicht das einzige Profil dar. Sie herrschen vor bei der Applikation der Zange und ihre
Häufigkeit nimmt $a b$, wenn, durch den Druck des Instrúments bedingt, $\mathrm{U}$ - und W-förmige Dezelerationen in den Vordergrund treten. Wenn sich die Effekte von Kopfkompressionen, die durch die Zange oder uterine Kontraktionen verursacht sind, ähneln, dann könnten $U$ - oder Wförmige Dezelerationen, wie sie während der Wehen aufgezeichnet werden, auch das Ergebnis von starker Kopfkompression im Geburtskanal sein; sie müssen nicht unbedingt auf Plazentainsuffizienz oder Nabelschnurkomplikationen zurückzuführen sein.

Wir fanden keine Korrelation zwischen Herzfrequenzmuster, wie sie während der Wehen aufgezeichnet werden, und Dezelerationen, die zum Zeitpunkt der Zangenanwendung auftreten. Darüberhinaus traten stärker abweichende Herzfrequenzmuster bei unterentwickelten Feten auf.

Schließlich kann Bradykardie nicht in Beziehung zur Zangengeburt gesetzt werden und tritt auch bei spontanen Geburten auf.

Schlüsselwörter: Fetale Kopfkompression, Forceps, Herzfrequenz, V-, W- und U-formige Dezelerationen.

Résumé

\section{Modèles def réquence cardiaque foetale pendant l'opération}

Malgré le très grand nombre d'études effectuées sur les changements de la fréquence cardiaque foetale (FCF) au cours du travail de l'accouchement, beaucoup de questions n'ont pas encore trouvé de réponse, notamment en ce qui concerne les mécanismes cuasals et le pronostic.

Plusieurs études récentes ont démontré que les modèles de fréquence cardiaque "de mauvais augure» ont une valeur de pronostic très basse. Par contre, on a pu constater la préçence de décélérations cardiaques «physiologiques» dans des cas de problèmes foetaux graves, $y$ compris de morts intra partum.

Et c'est en vue d'approfondir l'examen de ce sujet que nous avons décidé d'étudier les effets de la compression de la tête du foetus sur la FCF en cours d'opération au forceps.

Parturientes et méthodes: L'étude a porté sur 31 parturientes à terme dont les bébés ont été accouchés par l'emploi de forceps au niveau inférieur ou moyen. L'enregistrement continu de la FCF et de la pression intraamniotique avait été mis en route dès que le sujet avait atteint $4-6 \mathrm{~cm}$ et n'avait été stoppé qu'à la période néonatale directe. La courbe de FCF a été observée pendant les différentes phases de l'opération: application du forceps, blocage des bras du forceps, première traction, traction finale et couronnement de la tête foetale et, enfin, extraction du forceps.

Afin d'éliminer les variations de la FCF causées par l'activité utérine et les problèmes du cordon ombilical, les manoeuvres ont été effectuées dans les intervalles situés entre deux contractions utérines et les cas de complication ombilicale ont été exclus de l'étude.

Les décélérations cardiaques ont été classées selon leur forme.

Résultats: Fig. 1-3 Tab. II-III

Application du forceps: La ligne de base normale constante avec oscillations légères est prédominantc. Les décélérations en forme de $\mathrm{V}$ atténuée sont nombreuses; la FCF se normalise au cours de la manoeuvre.

Blocage des bras du forceps:

La ligne de base normale constante prédomine encore. Les décélérations sont nombreuses et réparties presqu'égale ment entre V-W et U. Leur amplitude est supérieure à celle de la phase précédente. Une bradycardie persistante et une tachycardie brusque peuvent être observées occasionnellement.

Premières tractions: Très peu de cas conservent une ligne de base normale. On observe un accroissement brusque du nombre et de l'amplitude des décélérations. Les décélérations en forme de $\mathbf{V}$ sont nombreuses, mais celles en $W$ ou $U$ prédominent. Une bradycardic persistante et une tachycardie brusque se manifestent parfois. La fréquence cardiaque se normalise de façon caractéristique après l'interruption de la manoeuvre.

Traction finale et couronnement de la tête du foetus:

Une baisse jusqu'à bradycardie persistante qui se maintient pendant la relâche d'une traction domine nettement durant cette phase.

Relache du forceps: La bradycardie persiste.

\section{Commentaire}

La bradycardie en forme de $\mathrm{V}$ se produit sans aucun doute pendant la compression crânienne, mais ce n'est pas le seul modèle. Elle prédomine pendant l'application du forceps et sa fréquence décroît à mesure qu'augmente la pression exercée par l'instrument et que les décélérations en forme d'U et de $W$ prédominent à leur tour. Si les effets de la compression crâniennc produite par les forccps ou les contractions utérines sont similaires, il se pourrait que les décléerations $\mathrm{U}$ ou $\mathrm{W}$ enregistréees en cours de travail résultent clles aussi d'une fortc compression crânienne dans le canal de naissance ct non pas obligatoirement d'une insuffisance placentaire ou de problèmes ombilicaux. 
Nous n'avons trouvé aucune corrélation entre les modèles de fréquence cardiaque enregistrés pendant le travail et la décélération observée au moment des manoeuvres avec forceps. Par ailleurs, des modèles de FCF plus graves ont pu être observés dans des cas de foetus avec dépression.
La bradycardie finale n'a pas de corrélation avec l'amploi des forceps et peut se manifester aussi dans des accouchements spontanés.

Mots-clés: Compression de la tête du foetus, décélérations en forme de $\mathrm{V}$, de $\mathrm{W}$ ou d'U, forceps, fréquence cardiaque.

\section{Acknowledgement}

This research has been supported in part by a grant from Fundacion Creole Caracas, Venezuela and Sears Roebuck de Venezuela.

Bibliography

[1] ARELlano HERNANDEZ, G., C. MENDEZ BAUER, J. J. POSEIRO., F. AGUERO LUGONES., A. BEAUQUIS., R. CALDEYRO BARCIA: Efectos de la compresion de la cabeza fetal, de la fontanela $y$ del cordon umbilical sobre la frecuencia cardiaca. Institute Neurological Diseases and Blindness, Nat. Institutes of Health, Public Health Service U.S.A., grant NB-03635-02 and Rockfeller Foundation, New York grant R.F.61043 p. 433.

[2] BEARD, R. W., G. M. FILSHIE, C. A. KNIGHT, G. M. ROBERTS: The significance of the changes in the continuous fetal heart rate in the first stage of labor. J. Obstet. Gynec. Brit. Cwlth. 78 (1971) 865

[3] CALDEYRO, B. R., C. MENDEZ BAUER, J. J. POSEIRO, L. A. ESCARCENA, S. V. POSE, J. BENIARZ, I. ARNT, L. GULIN, O. ALTHABE: Control of human heart rate during labor. In: CASSELS, D. E., The heart and circulation in the new born and infant. Grune \& Stratton, New York, London, 1966

[4] CIBILS, L. A.: Clinical significance of fetal heart rate patterns during labor. II late decelerations. Amer. J. Obstet. Gynec. 123 (1975) 473

[5] CHUNG, F., E. H. HON: The electronic evaluation of fetal heart rate: Ie with pressure on the fetal skull. Obstet. and Gynec. 13 (1959) 633

[6] HON, E. H.: The diagnosis of fetal distress. Clin. Obstet. Gynec. 3 (1960) 860

[7] KELly, J. V.: Compression of the fetal brain. Amer. J. Obstet. Gynec. 85 (1963) 687

[8] KELLY, J. V.: Instrument delivery and the fetal heart rate. Amer. J. Obstet. Gynec. 87 (1963) 529

[9] KELLY, J. V., G. SINES: An assessment of the compression and traction forces of obstetrical forceps. Amer. J. Obstet. Gynec. 96 (1966) 521

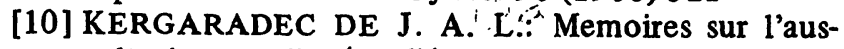
cultacion appliqué a l'étude de la grossesse. Paris 1822

[11] MANN, L. I., A. CARMichaEL, S. DUCHIN: The effect of head compression on FHR, brain metabolism and function. Obstet. and Gynec. 39 (1972) 721

[12] MENDEZ BAUER, C., J.J.POSEIRO,G.ARELLANO HERNANDEZ, M. A. ZAMBRANA, R. CALDEYRO BARCIA: Effects of atropine on the heart rate of the human fetus during labor. Amer. J. Obstet. Gynec. 85 (1963) 1033

[12a] MENDEZ-BAUER, C., A. RUIZ CANSECO, M. ANDUJAR RUIZ, A. MENEDEZ, J. ARROYO, R. D. GARDI, V. SASTRY, J. ZAMARRIEGO CRESPO.: Early decelerations of the fetal heart rate from occlusion of the umbilical cord. J. Perinat. Med. 6 (1978)

[13] MISRAHY, G. A., A. V. BERAN, J. F. SPRADLEY, U. P. GARWOOD: Fetal brain oxygen. Amer. J. Physiol. 199 (1960) 959

[14] MOCSARY, P., J. GAAL, B. KOMAROMY, G. V. MIHALY, O. POHANKA, S. SURANYI: Relationship between fetal intracranial pressure and fetal heart rate during labor. Amer. J. Obstet. Gynec. 106 (1970) 407

[15] PAUL, W. M., E.J. QUILLIGAN, T. MACLACHLAN: Cardiovascular phenomenon associated with fetal head compression. Amer. J. Obstet. Gynec. 90 (1964) 824

[16] PEARSE, W. H.: Electronic recording of forceps delivery. Amer. J. Obstet. Gynec. 86 (1963) 43

[17] SHENKER, L.: Clinical experiences with fetal heart rate monitoring of one thousand patients in labor. Amer. J. Obstet. Gynec. 115 (1973) 1111

[18] SCHIFRIN, B. S., L. DAME: Fețal heart rate patterns: Prediction of Apgar score. J.A.M.A. 219 (1972) 1322

[19] SUREAU, C.: The stress of labor. In: ALADJEM, S., K. BROWN: Clinical perinatology. Mosby, Saint Louis 1974

[20] WOOD, C., W. NEWMAN, J. LUMLEY, J. HAMMOND: Classifications of the fetal heart rate in relation to fetal scalp blood measurements and Apgar score. Amer. J. Obstet. Gynec. 105 (1969) 942

[21] ZILIANTI, M., J. ALLER, O. AGUERO: Equilibrio acido base de la sangre fetal durante el trabajo de parto. Rev. Obstet. Ginec. Venez. 31 (1971) 227

[22] ZILIANTI, M., S. C. LEON, F.. CABELLO, J. BENZAQUEN, M. ROMERO, M. A. ESTRADA: Studies on fetal bradycardia during birth process: I. Obstet. and Gynec. 42 (1973) 831

Received and accepted November 22, 1977. 